\title{
THE RETIREMENT CONSUMPTION CONUNDRUM: EVIDENCE FROM A CONSUMPTION SURVEY
}

\author{
Jonathan Fisher, David S. Johnson, Joseph Marchand, Timothy M. Smeeding, \\ and Barbara Boyle Torrey \\ CRR WP 2005-14 \\ Released: December 2005 \\ Draft Submitted: October 2005
}

\author{
Center for Retirement Research at Boston College \\ 550 Fulton Hall \\ 140 Commonwealth Ave. \\ Chestnut Hill, MA 02467 \\ Tel: 617-552-1762 Fax: 617-552-1750 \\ http://www.bc.edu/crr
}

\begin{abstract}
* Jonathan Fisher is a research economist on consumer expenditures at the Bureau of Labor Statistics. Joseph Marchand is a research associate at the Center for Policy Research at Syracuse University. Timothy Smeeding, Ph.D., is an economist and the Maxwell Professor of Public Policy at The Maxwell School of Citizenship and Public Affairs, Syracuse University. Fisher and Johnson: e-mail: fisher.jonathan@bls.gov and johnson.david.scott@bls.gov; Marchand and Smeeding: email: jtmarcha@maxwell.syr.edu and tmsmeed@maxwell.syr.edu. Torrey: e-mail: btorrey@prb.org. Corresponding authors are Fisher and Smeeding. The research reported herein was performed, in part, pursuant to a grant from the U.S. Social Security Administration (SSA) funded as part of the Retirement Research Consortium. The findings and conclusions expressed are solely those of the authors and do not represent the views of SSA, any agency of the Federal government, Syracuse University or the Center for Retirement Research at Boston College. The authors want to thank the Center for Retirement Research at Boston College and the Social Security Administration for their support of this research. Kati Foley provided excellent help with graphics and table design, and Martha Bonney provided much needed editorial assistance.
\end{abstract}

(C) 2005, by Jonathan Fisher, David S. Johnson, Joseph Marchand, Timothy M. Smeeding, and Barbara Boyle Torrey. All rights reserved. Short sections of text, not to exceed two paragraphs, may be quoted without explicit permission provided that full credit, including () notice, is given to the source. 


\section{About the Center for Retirement Research}

The Center for Retirement Research at Boston College, part of a consortium that includes a parallel centers at the University of Michigan and the National Bureau of Economic Research, was established in 1998 through a grant from the Social Security Administration. The goals of the Center are to promote research on retirement issues, to transmit new findings to the policy community and the public, to help train new scholars, and to broaden access to valuable data sources. Through these initiatives, the Center hopes to forge a strong link between the academic and policy communities around an issue of critical importance to the nation's future.

\section{Center for Retirement Research at Boston College \\ 550 Fulton Hall \\ 140 Commonwealth Ave. \\ Chestnut Hill, MA 02467 \\ phone: 617-552-1762 fax: 617-552-0191 \\ e-mail: crr@bc.edu \\ http://www.bc.edu/crr}

\section{Affiliated Institutions:}

American Enterprise Institute

The Brookings Institution

Center for Strategic and International Studies

Massachusetts Institute of Technology

Syracuse University

Urban Institute 


\begin{abstract}
While the life-cycle hypothesis predicts that consumption remains smooth during the transition from work into retirement, recent studies have shown that consumption declines at retirement. This empirical result has been referred to as the retirement consumption puzzle. Previous literature has most often relied on food expenditures to estimate the decline in consumption at retirement.

We add to this literature by using broader definitions of consumption data from the Consumer Expenditure Survey (CEX), which is a survey designed to estimate total household expenditures. We conduct cohort analysis, using data on four cohorts over 20 years from 1984 to 2003 . Our results using only food expenditures are on the lower end of the distribution of existing results. As we use broader measures of consumption, our results suggest that the retirement consumption conundrum decreases by more than half. Further, another contribution of this analysis is to widen the focus of the study of the well-being of the elderly. The retirement consumption puzzle does not tell the whole story on the well-being of the elderly. While we find that consumption-expenditures decrease by about 2.5 percent when individuals retire, expenditures continue to decline at about a rate of 1 percent per year after that.
\end{abstract}

JEL codes: J26; D91; D12 


\section{Introduction}

The life-cycle hypothesis predicts that consumption remains smooth during the transition from work into retirement (Modigliani and Brumberg 1954). Yet recent studies have shown that consumption declines at retirement. This decline has increasingly been referred to as the retirement consumption puzzle. The observed decline raises questions about whether the lifecycle hypothesis is correct or whether people underestimate their needs in retirement. Two concerns, however, raise questions about whether the consumption decreases are measured correctly: most studies use food expenditures as a proxy for total consumption, which may not be appropriate, and the estimated declines in consumption at retirement vary widely, from 4 to 17 percent.

This is an increasingly important issue because of the large number of people who are approaching retirement. In 2000, 22 percent of the U.S. population was 45 to 64 years old and will be retiring in the next twenty years. If consumption declines immediately after retirement, it would be critical for retirement program planners to know if the declines are in durable or nondurable consumption, in discretionary or essential kinds of consumption, and whether the declines continue after retirement. Understanding consumption changes among the newly retired is also important for individuals who are trying to assess how much income they will need in their retirement, what the experience has been of cohorts older than themselves, and what more they need to do before retireme nt to continue to enjoy the same level of economic well-being that they now experience.

This study contributes new data analysis and insights to a growing literature on how consumption changes at retirement and beyond. We use cohort analyses of the Consumer Expenditure Survey (CEX), which is designed specifically to estimate consumption-expenditures 
of households. We follow four age cohorts for twenty years, from 1984 to 2003, to track how consumption changed as each cohort entered retirement and then aged. We find results for a decline in food expenditures at retirement that are consistent with the existing research However, using a measure of total expenditures, we cut the level of consumption decline in half. Then, we eliminate the decline altogether under a third definition of consumption that estimates the flow of services from durable goods. We conclude that as the definition of consumption broadens, the level of decline during the transition between work and retirement grows smaller. As a result, the so-called retirement consumption puzzle declines in importance, the broader the definition of consumption.

Research on the retirement consumption conundrum is not new. Hamermesh (1984) used the Retirement History Survey (RHS) to examine two waves of the panel study and found a 9 percent drop in consumption, leading to a negatively sloped consumption profile for people in their 60s. More recently, a number of other studies have asked about retirement consumption using different data. All but one study find a decrease in consumption-expenditure within a year or two after retirement, although the size of the decrease varies (Table 1). In the United States, the average decrease in consumption right after retirement in six recent studies was about 9 percent, with a range between 4 and 17 percent. $^{1}$ To the contrary, one recent study found a small increase of 3 percent on a small sample size for one cohort of retirees (Hurd and Rohwedder 2005).

Several reasons may account for differences in the estimated declines in consumption at retirement. Definitions of retirement differ in the studies summarized in Table 1. Some studies use age and work status as a proxy for retirement. Others assume a person is retired if their

\footnotetext{
${ }^{1}$ Banks, Blundell, and Tanner (1998) use the British Family Expenditure Survey and find a 2 to 3 percent decrease in consumption of retirees in the United Kingdom.
} 
hours worked are less than a specific amount. Another reason for differences in estimated changes in consumption may be that four different data sets have been used to address this question, each with different strengths and weaknesses.

Two recent studies used the Panel Study of Income Dynamics (PSID) (Lundberg, Startz, and Stillman 2003; Hurst 2003). The number of PSID respondents reaching retirement, however, is small, and the consumption data are limited to food expenditures. Both studies found substantial average declines in food expenditures as respondents moved from work to retirement. Bernheim, Skinner, and Weinberg (2001) went beyond food expenditures in the PSID and imputed total consumption-expenditures using the CEX, thus combining the strength of a long panel study with the detailed consumption data of the CEX. They found a 14 percent decline in mean expenditures in the first two years of retirement. Further, Bernheim, Skinner, and Weinberg (2001) set forth the theoretical basis for their study and for all subsequent studies on the retirement cons umption conundrum.

The Health and Retirement Survey (HRS) has also been used to investigate the retirement consumption issue. The HRS, which began in 1992, has the considerable advantage of being a panel study focused on the aging population. Haider and Stephens (2004), using the HRS, find that retirement does not affect food expenditures. However, when using the older Retirement and Health Survey (RHS), they find that food expenditures fall by 7 to 11 percent within one year after retirement.

Aguiar and Hurst (2005) use the Continuing Survey of Food Intake and Individuals to examine food expenditures in more detail. Using food expenditures along with data on actual food eaten, they find that while food expenditures decline 17 percent at retirement, the quantity and quality of food consumed did not change. They conclude that given time to produce food 
at home and additional time to shop for bargains, the elderly spent less on food while maintaining their well-being.

Two other papers move beyond food expenditures and use broader measures of consumption, which include all non-durables. Hurd and Rohwedder (2005) use the HRS, but take advantage of a recently added feature, the Consumption and Activities Mail Survey module (CAMS), which provides more in-depth spend ing data. Hurd and Rohwedder (2005) use the two available waves of CAMS (2001 and 2003) and find that people report that total spending increases by 3 percent within two years after retirement. They caution, however, that the sample sizes are small $(n=191, \mathrm{p} 27)$ and more data will be needed before definitive conclusions can be made.

Finally, Laitner and Silverman (2005) use the CEX, which has the largest sample size of any of the surveys used and contains detailed consumption data. Their analysis creates a pseudo panel for each age (20 to 79 years old) and year (1984 to 1999). They find a 16 percent drop in total consumption upon retirement. ${ }^{2}$ Rather than use the expenditures as defined in the CEX, Laitner and Silverman (2005) adjust CEX total consumption to match the National Income and Product Accounts (NIPA) aggregate levels. Further, to address the retirement consumption puzzle, they create a change in consumption for each age-year cohort and use it as the dependent variable. As the main independent variable, they use an imputed probability of the household head being retired.

Our study also uses the CEX to investigate cohort trends in consumption as each cohort approaches and enters retirement, but our approach differs from that of Laitner and Silverman (2005). We use the CEX data directly and focus only on people aged 50 years and older. The

\footnotetext{
${ }^{2}$ Blau (2005) also uses the CEX to estimate the retirement consumption puzzle but uses a dummy variable for whether 50- to 80-year-olds are employed or not. While Blau (2005) adds to our understanding of the role that constraints unique to the elderly play in a life-cycle model, the empirical application is not as relevant in this case.
} 
CEX has considerable strengths in addressing the question of changes in consumption upon retiring. The sample sizes are large. We begin with 2,588 individuals aged 50 years and older in 1984 and follow five-year cohorts for the next 20 years (see Appendix Table A1). The CEX also contains the highest quality data collected on personal consumption of both durables and non-durables of any survey, and it provides cohort and consumption data on a consistent basis from 1984. Our study exploits all of these CEX strengths to compensate, in part, for the fact that, because it is not longitudinal, it cannot follow the behavior of specific individuals over time. However, the CEX can follow cohorts' consumption behavior, and we believe that cohort consumption provides useful insights for issues concerning retirement.

\section{The Data and Empirical Specifications}

The Consumer Expenditure Survey (CEX) is a continuing quarterly survey. Data are collected from consumer units and the individuals in these consumer units five times over a 13month period. ${ }^{3}$ The survey also collects an inventory of certain durable goods: homes, real estate, vehicles, and major appliances. In this study, the data are analyzed every five years from $1983 / 1984$ to 2003 . The consumption of four different five-year cohorts from age 50 to 80-plus is tracked over time, which allows us to observe the cohort dynamics and provides a unique window on group economic behavior. Cohorts, however, are not as flexible as individual longitudinal data, which allows researchers to draw conclusions about individual behavior (Burkhauser and Smeeding 2001).

\footnotetext{
${ }^{3}$ A consumer unit consists of members of a household who are related or share at least 2 out of 3 major expenditures: housing, food, and other living expenses. A person living alone is a single consumer unit. This article uses the terms consumer unit and household interchangeably. However, they are not always identical. A few households consist of more than one consumer unit. Therefore, there are approximately 3 percent more consumer units than households.
} 
One shortcoming of using a household or consumer unit as the unit of measurement is that it does not take into account differences in household size. Therefore, we disaggregate household information by age of each individual within the household so that we can examine the consumption of individuals by age group. We adjust the consumption resources of a consumer unit by an equivalence scale and use the consumer unit size (multiplied by the unit's sample weight) as a weight. Adjusting consumption in this manner yields 'equivalent resources per person' and provides us with a sample of individuals whose resources are given by the equivalent resources of their consumer unit. This scale is given by the square root of family size and indicates that the resources for a two-person family must be 41 percent more than that of a single-person family for the two families to have an equivalent standard of living. In general, the constant elasticity scales are given by (family size) $)^{e}$, in which $e$ is the scale elasticity. Notice that if the elasticity equals one, then the scale equals family size; there are no assumed economies of scale in living arrangement and the equivalent resources are simply the per capita resources. Alternatively, if the elasticity equals zero, then there is no adjustment for family size; there are complete economies of scale in living, and the marginal cost of another person is zero. Our chosen elasticity of 0.5 lies halfway between these two implausible extremes (Burkhauser and Smeeding 1994). ${ }^{4}$

At least two biases exist in cohort analysis. One is caused by differential mortality rates within the same cohort of individuals. People with lower socio-economic status (SES) die earlier than people with higher status (Singer and Ryff 2001). This means that as each cohort ages, it is composed of an increasing number of people with higher economic status who could presumably afford more consumption. To judge the size of this bias, we used education as a

\footnotetext{
${ }^{4}$ We also used a three-parameter equivalence scale and the Census Bureau Poverty Equivalence Scales, and the quantitative results are similar to the ones presented in the text. These results are available upon request.
} 
proxy for SES and calculated how the percentage of each cohort with a high school education or less changed as it aged. There was almost no detectable change before age 60. But the percentage of the cohort with only high school or less education decreased 9 percent from age s 65-69 to $80+$ in the oldest cohort. This means that cohort comparisons of age groups above ages 65 to 69 will tend to underestimate decreases in consumption that would have occurred if there were not differential mortality.

Another bias in our analysis is that the people who retired in each cohort may not be a random selection of the cohort. At younger ages, retirees may be wealthy and can afford to retire young, or they may be unhealthy and unable to work. At older ages, those still working may also be at two ends of the wealth distribution: the poor who need to work and the wealthy who love to work.

The definition of retirement used in this paper has two criteria: individuals report zero earned income and list retirement as the reason for no earnings. This is the most restrictive definition of the term "retirement" of all of the papers reviewed. Most people retire between 60 and 70 years old in the United States. The average age of retirement in the PSID sample is 62.7 (Hurst 2003); the average age in the Health and Retirement Study is 62.6 (Laitner and Silverman 2005). In the CEX, 56 percent of 65- to 69-year-olds report not working because of retirement (Table A1). Because of concerns about the heterogeneity of both the retired and non-retired in the tails of the age distribution, our analysis focuses on two groups: the retired and non-retired in each cohort between the ages of 60 and 70 years.

We also use median instead of mean equivalent measures because of the skewed distribution of consumption. All consumption data are in real 2003 dollars, using the item indexes from the CPI research series (CPI-U-RS). 
In addition to food expenditures, we develop two other resource measures to test the sensitivity of our results:

- Consumption-expenditures, which is the spending for current consumption. It includes outlays for housing, food, transportation, apparel, medical care, entertainment, gifts to organizations or persons outside the consumer unit, and miscellaneous items for the consumer unit. Excluded are expenditures for pensions and social security, savings, and life insurance. Most studies summarized in Table 1 use the term consumption as equivalent to consumption-expenditures used in this paper.

- Consumption-flows, which reflects current outlays for non-housing items and the flow of services from housing. Consumption-flows equal consumption-expenditures less the costs of homeownership plus the rental equivalence of the owned home. For renters, this means that consumption-expenditures equal consumption-flows. Although data for other durables exist, the flows are much smaller than they are for housing and do not affect the conclusions in this study. ${ }^{5}$ To incorporate the consumption-flow value of housing, we first converted the value of the home into a flow variable based on the household's report

\footnotetext{
${ }^{5}$ See the Data Appendix for a more detailed explanation of consumption-expenditures and consumption-flows. Our definition of consumption-flows differs in two ways from previous consumption-flow measures. For example, Johnson, Smeeding, and Torrey (2005), who also created a measure of consumption-flows, estimated the consumption-flows of owned homes and vehicles; we use only the consumption-flow for owned homes. The second difference is that we include gifts and cash contributions in our measure of consumption-expenditures and consumption-flows, while other research has excluded these two.
} 
of the home's rental value. ${ }^{6}$ We then replaced the household's expenditures for its owned dwelling with the rental value of the home. ${ }^{7}$

\section{Results}

The retirement consumption conundrum focuses on what happens at the retirement phase transition. To estimate the change in consumption at retirement for our cohorts, we examine the change in consumption using three measures: food expenditures, consumption-expenditures, and consumption-flows. We also compare the median consumption of each cohort when they are aged 60 to 64 and not retired to the median consumption of the same cohort when they are aged 65 to 69 and retired. These age breaks represent when the big increase in retirement within a cohort occurs. Approximately 21 percent of individuals are retired when they are 60 to 64, while 55 percent are retired when they are 65 to 69 (Appendix Table A1).

\section{Food Expenditures}

As noted above, most previous studies use food expenditures as a proxy for consumptionexpenditures. Using just food expenditures with the CEX cohorts, the results for two of the cohorts matches earlier results, with cohort 2 and cohort 3 experiencing an 8 and 10 percent decline, respectively (Table 2). Food expenditures for cohort 1 did not change around retirement; however, if we just focus on food consumed at home for cohort 1 , then we find that food

\footnotetext{
${ }^{6}$ Specifically, we replace mortgage interest, property taxes, home insurance, and maintenance and repair costs in consumption-expenditures with rental equivalence in our measure of consumption-flows. The estimate of rental equivalence comes from the CEX question: "If someone were to rent your home today, how much do you think it would rent for monthly, unfurnished and without utilities?".

${ }^{7}$ The accuracy of the reporting of home values has been an area of study and interest to us because we rely on selfreported rental value of owned homes. Different studies of the bias in self-reported home values all point in the same direction. Kiel and Zabel (1999) used the American Housing Survey and found that self-reports exceeded real values by 5 percent on average, with a range of -2 to +16 percent. A more recent study using the HRS and AHEAD suggest that home values are overestimated by 15 to 20 percent (Venti and Wise 2001). Therefore, an upward bias on self-reported home values may also exist in the CEX.
} 
expenditures decreased by 4 percent around retirement. But food alone is a very restrictive definition of either consumption or expenditure.

\section{Consumption-Expenditures}

Next we focus on measures of consumption that more accurately reflect the broader wellbeing of individuals. We first look at consumption-expenditures, which represent a measure of total out-of-pocket expenditures for the individual.

On average, consumption-expenditures decrease after age 55 (Fisher and Johnson 2002). Table 3 shows that for the youngest cohort (cohort 1), median equivalent consumptionexpenditures fell from $\$ 18,624$ when the cohort was 55 to 59 years old in 1988 to $\$ 16,193$ when it was 70 to 74 years old in 2003. Across cohorts, however, consumption-expenditures rise for the same age groups from the oldest to the youngest cohorts. For example, cohort 1 had median consumption-expenditures at age 65 to 69 that were 16 percent higher in real terms than the median for the oldest cohort (cohort 4) at the same age. At age 70 to 74 , the expenditures of the youngest cohort were 8 percent higher than the expenditures for the cohort that was the same age 15 years earlier. This is consistent with increases in overall economic well-being of the elderly over time (Smolensky, Danziger, and Gottschalk 1988; Engelhardt and Gruber 2004).

The retirement consumption puzzle focuses specifically on the transition into retirement. Table 3 also highlights the consumption-expenditures by retired and not retired for each cohort and age. Of those not retired in cohort 1 aged 60 to 64, median equivalent consumptionexpenditures equaled $\$ 17,290$. Five years later in 1998,58 percent of that cohort was retired, and expenditures of the retired members of the cohort increased by 1.3 percent to $\$ 17,514$. This increase is similar to what Hurd and Rotwedder (2005) found using the HRS data from 2001 and 2003. 
Cohort 2, which is five years older than cohort 1 , had higher consumption-expenditures than cohort 1 when they were working at age 60 to 64 . Cohort 2 had a drop of 8 percent in the median consumption-expenditures between their working members at ages 60 to 64 and their retired members five years later. Cohort 3 had a drop of 3 percent in their median consumptionexpenditures in the same comparison.

Cohort 2's decrease in consumption expenditures at retirement is confounded by the early 1990s recession. Between 1988 and 1993, median expenditures decreased for all cohorts (Table 3). Between 1993 and 1998, median expenditures increased for every cohort except cohort 3, which may help explain why consumption expenditures actually increased when cohort 1 retired. As both periods affected earnings, expectations, and financial wealth, 'period' effects might be partly offsetting both cohort and aging effects in this case. ${ }^{8}$

Caution must be used in interpreting our cohort results, however, because of the possible selection bias in those who retire within a cohort. In both cohorts 1 and 3, consumptionexpenditures increased considerably for the non-retired at ages 65 to 69 after some of the cohort retired at ages 60 to 64 . This suggests that the people who retired earlier may have had lower expenditures when they were still working than those members of the cohort who continued to work. One clear conclusion from Table 2 and Table 3 is that the size of the drop in expenditures is smaller when using total consumption-expenditures than when using food expenditures.

The other thing to take away from consumption-expenditures is that focusing on the years around retirement alone misses a big part of the story of the changing well-being of the elderly. After ages 65 to 69, the retired cohorts' median consumption-expenditures continued to decline

\footnotetext{
${ }^{8}$ It is interesting to note that Haider and Stephens (2004) use data from the late 1990s in the HRS and find that the change in food expenditures at retirement is statistically insignificant. They dismiss these results as different from those found in the RHS and PSID and therefore do not further explain this new puzzle. It may be that period effects or cohort effects from the late 1990s may explain their results in the HRS and our results for cohort 1.
} 
slowly. In the ten years after ages 65 to 69 , median expenditures declined 6 percent for cohort 2, 8 percent for cohort 3 , and 1 percent for cohort 4 . Another way to measure the change is that the median expenditures of the 75- to 79-year-olds who were retired in cohort 2 were 13 percent lower than they had been 15 years before for the same cohort when they were working. For cohort 3 , the decline in median expenditures over 15 years was 18 percent. That represents a decline in median expenditures of about 1 percent a year over fifteen years for those two cohorts. Thus, we concur that consumption-expenditures are decreasing in retirement but that the decline is more gradual than previous research suggests.

\section{Consumption-Flows}

The motivation for studying how consumption changes in the retirement transition is not merely to test the life-cycle hypothesis, but also to determine whether well-being changes when people retire. In order to address both of these issues, consumption-expenditures may not be the most appropriate concept. Consumption-expenditures are used because, as a resource measure, they are unambiguous, commonly used, and readily understandable. Many researchers have suggested, however, that if well-being is the purpose for studying consumption, then a broader measure of consumption-expenditures would be more appropriate (Cutler and Katz 1991; Slesnick 1994; Sabelhaus and Schneider 1997; Johnson and Shipp 1997; Johnson, Smeeding and Torrey 2005; Jorgenson 1998). For example, it would be important not only to measure consumption-expenditures for current goods and services but also the flow of consumption services from housing. This flow of services is consumed regularly, but the costs are paid up front, outside the period that is captured in a consumption-expenditure framework. This is particularly important when the older population is the subject of the analysis, because their 
homes are not only their largest consumption-expenditure, they are also their most significant durable and largest asset.

Housing consumption becomes even more important under the concept of consumptionflows than with consumption-expenditures. For renters, the consumption-flow and consumptionexpenditure for housing are equal, but the large majority of elderly are homeowners. The CEX data suggest that 85 percent of individuals of cohort 1, who were 65 and older, were homeowners in 2003, and of those over 77 percent had no mortgage. ${ }^{9}$ Therefore, consumption-flows will be higher than consumption-expenditures.

Table 4 indicates that housing flows are an even larger percentage of consumption-flows than are housing outlays as a share of consumption-expenditures. For cohort 1, aged 65 to 69 , the share of housing flows is 43 percent of total consumption-flows, while housing outlays comprise 32 percent of consumption-expenditures. This difference is even starker, considering that consumption-flows and consumption-expenditures do not differ for renters. Housing flows consistently increase as a share of consumption-flows as each cohort ages. Even if an elderly person stays in the same home, the consumption-flow of housing increases as the rental value increases.

This conversion of housing outlays to housing flows changes the perspective on life-cycle consumption as cohorts enter retirement. Table 5 compares consumption-flows for the nonretired 60- to 64-year-olds with the retired 65- to 69-year-olds of the same cohort five years later. For cohort 1, consumption-flows actually increase 16 percent for the retired who are 65 to 69 years old. For cohort 2, they decrease 4 percent and for cohort 3 they decrease 1 percent. Over a longer horizon, consumption-flows increase 6 percent for cohort 2 from those who are aged 60 to

\footnotetext{
${ }^{9}$ These estimates are somewhat higher than those found in the American Housing Survey (AHS). For all households headed by an individual aged 65 plus in 1999, the AHS estimated that 80 percent live in owner-occupied housing and that 75 percent had no mortgage. The AHS can be found at http://www.census.gov/hhes/www/housing.html.
} 
64 years and non-retired to those who are 75 to 79 years old and retired. The flows increased 1 percent for cohort 3 for the same age groups.

Consumption-flows, like consumption-expenditures, increase over time for the same age group in different cohorts. Consumption-flows for 65-69 year olds increased 17 percent from Cohort 4 to Cohort 1, the same increase as for expenditures. Consumption-flows for 70- to 74year-olds increased 12 percent compared with 8 percent for consumption-expenditures. The real improvement in consumption-expenditures and flows by age group over time is consistent regardless of which concept is used.

\section{Conclusions}

The retirement consumption puzzle changes character with each change in the definition of consumption. Table 6 summarizes the change using three different measures of consumption for cohorts 1, 2 and 3 who are non-retired at 60 to 64 years old and five years later when they are 65 to 69 and retired. The numbers presented in Table 6 are weighted averages of the equivalent values in the respective tables, not simple averages.

It can be seen from these summary statistics that as the definition of consumption broadens, the gap between consumption while working and consumption at retirement grows smaller. The decline using food expenditures is the greatest and is at the lower end of estimates in the studies cited in Table 1. Our estimated decline is over five years, however, rather than just the year or two around retirement. When we broaden the definition of consumption to consumption-expenditures, the decline at retirement is less than half the decline with food expenditures. When we broaden the concept of consumption further to include the flow of housing services (consumption-flows), consumption actually increases a small amount at 
retirement. These latter results are consistent with research showing that 80 percent of households do anticipate their retirement needs correctly and appear to save enough for their retirement when the value of housing is included (Engen, Gale, and Uccello 2004; Hurst 2003).

These conclusions are strongly influenced by the size of the housing outlays and by our measurement of housing flows. They suggest that an elderly person's home is a critical part of their social safety net. Housing expenditures, which may be viewed as the cost of keeping one's safety net in good repair, stay relatively level as cohorts age. Housing flows as a percent of consumption-flows increase each year as the rental value of the home increases.

Several other conclusions result from our research. First, food is not an ideal proxy for total consumption. In retirement, food expenditures decline faster than total expenditures do. Previous research relied on food expenditures because those data are readily available in longitudinal surveys (PSID, RHS, and HRS). However, the se longitudinal surveys began to include broader measures of consumption in the early 2000s, and the research using these surveys will need to be updated. Until then, researchers using the PSID, RHS, and HRS should be careful in making definitive statements about consumption when using food expenditures as a proxy for total consumption.

Second, research should also be careful in using age as a proxy for retirement. Without longitudinal data, most studies, including ours, have to rely on cohort data to detect behavior changes at retirement. But each age cohort is heterogeneous in terms of the fraction of the elderly retired. A substantial number of people work at least for some time during the year -- even at older ages. When we generalize about cohorts without separating out the retired and non-retired, conclusions about retirement consumption may be distorted. 
Finally, the focus on the retirement consumption puzzle is correct if the goal is to test the life-cycle hypothesis, but it does not tell the whole story on the well-being of the elderly. While we find that consumption-expenditures decrease by about 2.5 percent when individuals retire, expenditures continue to decline at about a rate of 1 percent per year after that. Consumptionflows, on the other hand, stay relatively constant or even increase after age 60 to 64 .

The biggest question this study raises, however, may be about the role of the home in the consumption of the elderly. The home looms so large in both consumption-expenditure and consumption-flow measurements that its role in retirement deserves more attention. Do the elderly at some point convert their housing consumption-flow into income? And, if so, do they do it with second mortgages, reverse annuity mortgages, or home equity loans? These and many other questions are beyond the scope of this paper but are logical extensions of what we have already learned about consumption-expenditures and consumption-flows of Americans as they enter retirement. 


\section{DATA APPENDIX}

\section{CEX Data}

To get an adequate sample size for each year, we use the four quarters of data for each year plus data from the last quarter from the year before and the first quarter for the year after. For 2003, this means we use data from the fourth quarter of 2002 to the first quarter of 2004. This allows us to have almost 3,000 individuals per year.

Our sample consists of four age cohorts. The youngest cohort, cohort 1, was 50 to 54 in 1983/84 and was born between 1929 and 1933. Cohort 2 was 55 to 59 in 1983/84. Our unit of analysis is the individual. For a married couple, we observe both the husband and wife if both were members of one of our four cohorts. If one is too young or too old while the other is within one of the cohorts, we use the one who belongs to the cohort and exclude the one who does not. To determine retirement status, the occupational status of the individual is used. Each individual is asked the occupation she received the most earnings from in the last year. One of the choices is for the individual to respond that she is not working because she is retired.

The consumption-expenditures measure includes the amount that the consumer unit actually spends for current consumption. This includes expenditures for food, housing, transportation, apparel, medical care, entertainment, gifts (of cash, goods and services) to organizations or persons outside the consumer unit, and miscellaneous items for the consumer unit. Excluded are expenditures for pensions and social security, savings, and life insurance.

Housing includes expenses associated with owning or renting a home or apartment, including rental payments, mortgage principal and interest, property taxes, maintenance, repairs, insurance, and utilities.

Transportation includes expenditures for the net purchase price of vehicles, finance charges, maintenance and repairs, insurance, rental, leases, licenses, gasoline and motor oil, and public transportation. Public transportation includes fares for mass transit, buses, airlines, taxis, school buses, and boats.

Medical care expenditures are for out-of-pocket expenses including payments for medical care insurance, medical services, and prescription drugs.

Entertainment expenditures are for fees and admissions, televisions, radios, sound equipment, pets, toys, playground equipment, and other entertainment supplies, equipment, and services.

Miscellaneous expenditures are for personal care services, reading, education, tobacco products and smoking supplies, alcoholic beverages, other lodging, and house furnishings and equipment.

To obtain our measure of consumption-flows, we estimate the service flow of homeownership. For the value of homeownership, we use the reported rental equivalence value obtained from the consumer unit. Consumer units who own their home are asked, "If someone were to rent your home today, how much do you think it would rent for monthly, unfurnished and without utilities?" The annualized value of this is then used for homeownership cost in place of the amount used in the definition of consumption-expenditures.

\section{Comparison to HRS-CAMS}

The Health and Retirement Survey included the Consumption and Activities Mail Survey module (CAMS) in 2001 and 2003. Butrica, Goldwyn and Johnson (2005) estimated shares of expenditures using the 2001 wave of CAMS. To match Butrica et al., we used 2001 CEX data, 
used per capita expenditures, and matched their definitions for the eight categories of expenditures used in their Table 1.

After manipulating our CEX data to match their definition of consumption-expenditure categories and their sample under study, the distribution of consumption shares using HRS and CEX data are comparable. Both show that the single largest expenditure for people 65 and over is for housing. For Butrica et al. and for the CEX, housing comprises 32 percent and 30 percent, respectively, of consumption-expenditures for all 65-74 year olds (see Appendix Table A2). Similarly, they find that medical/health care expenditures comprise 16 percent for 65-74 year olds, and we find it comprises 15 percent. For a more thorough comparison of the consumptionexpenditure measures in the two data sets, see Garner et al. (2005), who finds that the CEX covers more expenditures than does the CAMS, but that the differences in levels and shares are small. 


\section{REFERENCES}

Aguiar, Mark, and Erik Hurst. 2005. “Consumption vs. Expenditure.” Journal of Political Economy 113 (5): 919-948.

Banks, James, Richard Blundell, and Sarah Tanner. 1998. 'Is There a Retirement-Savings Puzzle?" American Economic Review 88 (4) (September): 769-788.

Bernheim, B. Douglas, Jonathan Skinner, and Steven Weinberg. 2001. "What Accounts for the Variation in Retirement Wealth among U.S. Households?" American Economic Review 91 (4) (September): 832-857.

Blau, David M. 2005. 'Retirement and Consumption in Life Cycle Model.” Unpublished manuscript. March.

Burkhauser, Richard V., and Timothy M. Smeeding. 1994. "Social Security Reform: A Budget Neutral Approach to Reducing Older Women's Disproportionate Risk of Poverty." Center for Policy Research, Policy Brief No. 2. Syracuse, NY: Syracuse University. http://wwwcpr.maxwell.syr.edu/pbriefs/pb2.pdf.

Burkhauser, Richard V., and Timothy M. Smeeding. 2001. "The Role of Micro-level Panel Data in Policy Research.” Schmollers Jahrbuch 121 (3): 1-32.

Butrica, Barbara A., Joshua H. Goldwyn, and Richard W. Johnson. 2005. “Understanding Expenditure Patterns in Retirement." Center for Retirement Research Working Paper No. 2005-03. Chestnut Hill, MA: Boston College. January. http://www.bc.edu/centers/crr/wp_2005-03.shtml 
Cutler, David M., and Lawrence F. Katz. 1991. "Rising Inequality? Changes in the Distribution of Income and Consumption in the 1980's." American Economic Review 82 (2): 546-551.

Engelhardt, Gary V., and Jonathan Gruber. 2004. "Social Security and the Evolution of Elderly Poverty.” NBER Working Paper No. W10466. Cambridge, MA: National Bureau of Economic Research. May.

Engen, Eric M., William G. Gale, and Cori Uccello. 2004. "Lifetime Earnings, Social Security Benefits, and the Adequacy of Retirement Wealth Accumulation." Center for Retirement Research WP 2004-10. Chestnut Hill, MA: Boston College. March. http://www.bc.edu/centers/crr/wp_2004-10.shtml

Fisher, J., and D. Johnson. 2002. "Consumption Mobility in the United States: Evidence from Two Panel Data Sets." Presented at Conference on Economic Mobility in America and Other Advanced Countries, Jerome Levy Economics Institute of Bard College.

Garner, Thesia, Michael D. Hurd, Laura Paszkiewicz, and Susann Rohwedder. 2005. "Comparing Spending Measures in the CES and CAMS." Ongoing research at RAND and the Bureau of Labor Statistics.

Haider, Steven J., and Melvin Stephens Jr. 2004. "Is There a Retirement-Consumption Puzzle? Evidence Using Subjective Retirement Expectations.” NBER Working Paper No. 10257. Cambridge, MA: National Bureau of Economic Research. February. http://papers.nber.org/papers/w10257

Hamermesh, Daniel S. 1984. "Consumption During Retirement: The Missing Link in the Life Cycle." Review of Economics and Statistics 66 (1) (February): 1-7. 
Hurd, Michael, and Susann Rohwedder. 2005. 'The Retirement-Consumption Puzzle:

Anticipated and Actual Declines in Spending at Retirement." Labor and Population Program WR-242. Santa Monica, CA: RAND. February. http://www.rand.org/publications/WR/WR242/

Hurst, Erik. 2003. "Grasshoppers, Ants, and Pre-Retirement Wealth: A Test of Permanent Income.” NBER Working Paper No. 10098. Cambridge, MA: National Bureau of Economic Research. November. http://papers.nber.org/papers/w10098

Johnson, David, and Stephanie Shipp. 1997. "Trends in Inequality Using ConsumptionExpenditures: The U.S. from 1960-1993." Review of Income and Wealth 43 (2) (June): $133-152$.

Johnson, David, Timothy M. Smeeding, and Barbara Boyle Torrey. 2005. "United States Inequality through the Prisms of Income and Consumption. " Monthly Labor Review 128 (4) (April): 11-24.

Jorgenson, Dale W. 1998. “Did We Lose the War on Poverty?” Journal of Economic Perspectives 12 (1): 79-96.

Kiel, Katherine A., and Jeffrey E. Zabel. 1999. "The Accuracy of Owner-Provided House Values: The 1978-1991 American Housing Survey." Real Estate Economics 27 (2) (Summer): 263-298.

Laitner, John, and Dan Silverman. 2005. "Estimating Life-Cycle Parameters from Consumption Behavior at Retirement.”NBER Working Paper No. 11163. Cambridge, MA: National Bureau of Economic Research. March. http://papers.nber.org/papers/w11163 
Lundberg, Shelly, Richard Startz, and Steven Stillman. 2003. "The Retirement-Consumption Puzzle: A Marital Bargaining Approach.” Journal of Public Economics 87 (5-6) (May): 1119-1218.

Modigliani, Franco, and Richard Brumberg. 1954. "Utility Analysis and the Consumption Function: An Interpretation of Cross-Section Data.” In Post-Kenyesian Economics, edited by Kenneth K. Kurihara. New Brunswick: Rutgers University Press.

Sabelhaus, John, and Ulrike Schneider. 1997. "Measuring the Distribution of Well- Being: Why Income and Consumption Give Different Answers." Applied Economics Quarterly 43 (2): 153-176.

Singer, Burton, and Carol D. Ryff. 2001. New Horizons in Health: An Integrative Approach. Washington, DC: National Academy Press.

Slesnick, Daniel T. 1994. "Cons umption, Needs and Inequality." International Economic Review 35 (3): 677-703.

Smolensky, Eugene, Sheldon Danziger, and Peter Gottschalk. 1988. "The Declining Significance of Age in the United States: Trends in the Well-Being of Children and the Elderly Since 1939.” Chapter 3 In The Vulnerable, edited by John L. Palmer, Timothy M. Smeeding, and Barbara Boyle Torrey. Washington, DC: Urban Institute Press, 29-54.

Venti, Steven F., and David A. Wise. 2001. "Aging and Housing Equity: Another Look." NBER Working Paper No. 8608. Cambridge, MA: National Bureau of Economic Research. November. http://papers.nber.org/papers/W8608 
TABLE 1

ESTIMATED DECREASES IN CONSUMPTION AFTER RETIREMENT

\begin{tabular}{|c|c|c|c|c|}
\hline Authors & Data Set & Estimated Change & Consumption & Retirement Definition \\
\hline $\begin{array}{c}\text { Bernheim, } \\
\text { Skinner, and } \\
\text { Weinberg (2001) }\end{array}$ & PSID (1978-1990) & $\begin{array}{l}\text { Unconditioned decrease in first two } \\
\text { years after retirement: } 14 \text { percent } \\
\text { (mean) and } 12 \text { percent (median) }\end{array}$ & $\begin{array}{l}\text { Imputed consumption- } \\
\text { expenditures using the } \\
\text { CEX Su rvey }\end{array}$ & $\begin{array}{l}\text { If no household member worked more than } 500 \\
\text { hours in the current year and subsequent years }\end{array}$ \\
\hline $\begin{array}{l}\text { Lundberg, Startz, } \\
\text { and Stillman } \\
(\mathbf{2 0 0 3 )}\end{array}$ & PSID (1979-1992) & $\begin{array}{l}9 \text { percent for married households } \\
\text { between the year before retirement to } \\
\text { the year after; insignificantly } \\
\text { different from zero for singles }\end{array}$ & $\begin{array}{l}\text { Food at home and food } \\
\text { away from home }\end{array}$ & $\begin{array}{l}\text { Most recent self-reported year of retirement for } \\
\text { husband or household head for singles }\end{array}$ \\
\hline $\begin{array}{c}\text { Haider and } \\
\text { Stephens (2004) }\end{array}$ & $\begin{array}{l}\text { RHS }(1969-1977) \\
\text { and HRS }(1992- \\
2000)\end{array}$ & $\begin{array}{l}\text { Between two years before retirement } \\
\text { and the year of retirement, food falls } \\
\text { by } 7 \text { to } 11 \text { percent when individuals } \\
\text { retire as expected in the RHS. HRS } \\
\text { consumption is not significantly } \\
\text { affected by retirement. }\end{array}$ & $\begin{array}{l}\text { Food at home and food } \\
\text { away from home }\end{array}$ & $\begin{array}{l}\text { The first year the male head of the household } \\
\text { reports being retired (and they instrument for } \\
\text { retirement using a question on when the } \\
\text { individual expects to retire) }\end{array}$ \\
\hline Hurst (2003) & PSID (1990-1999) & $\begin{array}{l}\text { Unconditioned decrease in food } \\
\text { between the three years before } \\
\text { retirement and the three years after } \\
\text { retirement: } 12 \text { percent (median) and } \\
4 \text { percent (mean) }\end{array}$ & $\begin{array}{l}\text { Food at home and food } \\
\text { away from home }\end{array}$ & $\begin{array}{c}\text { The first year the household reports being } \\
\text { retired }\end{array}$ \\
\hline $\begin{array}{l}\text { Aguair and Hurst } \\
\qquad(2005)\end{array}$ & $\begin{array}{l}\text { Continuing Survey } \\
\text { of Food Intake and } \\
\text { Individuals (1989 } \\
\text { and 1994) }\end{array}$ & $\begin{array}{l}\text { Consumption expenditures fall by } 17 \\
\text { percent at retirement, on average. }\end{array}$ & $\begin{array}{l}\text { Food at home and food } \\
\text { away from home }\end{array}$ & $\begin{array}{c}\text { If not working, the response to the question: } \\
\text { "which of the reasons on this card best describe } \\
\text { why you was not working at a paid job last } \\
\text { week?". }\end{array}$ \\
\hline $\begin{array}{c}\text { Hurd and } \\
\text { Rohwedder (2005) }\end{array}$ & $\begin{array}{c}\text { HRS-CAMS (2001, } \\
\text { 2003) }\end{array}$ & $\begin{array}{l}\text { "Actual spending" changes at } \\
\text { retirement are balanced between } \\
\text { increases and reductions. }\end{array}$ & Total spending & Self-reported: "Are you retired?" \\
\hline $\begin{array}{c}\text { Laitner and } \\
\text { Silverman }(2005)\end{array}$ & CEX (1984-2001) & $\begin{array}{c}\text { Retirement decreases consumption- } \\
\text { flows by } 16 \text { percent in the year of } \\
\text { retirement. }\end{array}$ & $\begin{array}{l}\text { CEX consumption- } \\
\text { flows adjusted to match } \\
\text { NIPA aggregates. }\end{array}$ & $\begin{array}{l}\text { Predicted probability of being retired; they use } \\
\text { the March CPS to obtain coefficients to predict } \\
\text { an age-year specific probability. }\end{array}$ \\
\hline
\end{tabular}




\section{TABLE 2}

\section{MEDIAN EQUIVALENT FOOD EXPENDITURES BY COHORT AND AGE}

\section{COHORT 1}

Total food ${ }^{1}$

Food at home

Food away from home

\section{COHORT 2}

Total food ${ }^{1}$

Food at home

Food away from home

\section{COHORT 3}

Total food ${ }^{1}$

Food at home

Food away from home

\section{Age 60-64 \\ Not retired \\ 1993}

3,324

2,666

542

1988

3,710

2,963

657

1984

3,703

2,831

625

$\begin{array}{rr}\begin{array}{r}\text { Age 65-69 } \\ \text { Retired }\end{array} & \text { \% } \text { change }^{2} \\ 1998 & \\ 3,351 & 0.8 \\ 2,568 & -3.7 \\ 631 & 16.4\end{array}$

1993

3,414

2,617

537

$-18.3$

1988

$3,333 \quad-10.0$

2,594

525

Source: Authors' calculations based on the Consumer Expenditure Survey (1984-2003).

${ }^{1}$ Because we use the medians, the sum of food at home and food away will not equal total food.

${ }^{2} \%$ change equals non-retired expenditures for 60-64 year olds minus the retired 65-69 year olds of the same cohort divided by the non-retired expenditures.

Notes: All data are in real \$2003 using the CPI-U-RS item indexes. We calculate median equivalent expenditures using the square root of family size as the equivalence scale. We weight all data to be representative of the U.S. elderly population. Our unit of observation is the individual. 


\section{TABLE 3}

MEDIAN EQUIVALENT CONSUMPTION EXPENDITURES BY COHORT AND AGE

\begin{tabular}{|c|c|c|c|c|c|c|c|}
\hline COHORT 1 & 1984 & 1988 & 1993 & 1998 & 2003 & & \\
\hline All & 17,819 & 18,624 & 17,129 & 18,358 & 16,193 & & \\
\hline Not retired & 17,722 & 18,737 & 17,290 & 19,593 & 18,251 & & \\
\hline Retired & 22,661 & 16,498 & 16,800 & 17,514 & 15,789 & & \\
\hline$\%$ change $^{1}$ & & & & $1.3 \%$ & & & \\
\hline COHORT 2 & & 1984 & 1988 & 1993 & 1998 & 2003 & \\
\hline All & & 17,150 & 17,277 & 17,079 & 17,474 & 16,011 & \\
\hline Not retired & & 17,175 & 18,050 & 17,608 & 18,832 & 18,466 & \\
\hline Retired & & 16,562 & 15,890 & 16,639 & 17,016 & 15,698 & \\
\hline$\%$ change $^{1}$ & & & & $-7.8 \%$ & & & \\
\hline COHORT 3 & & & 1984 & 1988 & 1993 & 1998 & 2003 \\
\hline All & & & 16,021 & 16,145 & 15,267 & 14,721 & 14,695 \\
\hline Not retired & & & 16,211 & 17,735 & 17,155 & 14,742 & 14,314 \\
\hline Retired & & & 15,840 & 15,709 & 14,488 & 14,525 & 14,695 \\
\hline$\%$ change $^{1}$ & & & & $-3.1 \%$ & & & \\
\hline COHORT 4 & & & & 1984 & 1988 & 1993 & 1998 \\
\hline All & & & & 15,893 & 15,026 & 13,536 & 14,215 \\
\hline Not retired & & & & 16,455 & 15,575 & 10,432 & 12,821 \\
\hline Retired & & & & 15,067 & 14,949 & 14,848 & 14,454 \\
\hline
\end{tabular}

Source: Consumer Expenditure Survey (CEX): 1984-2003.

${ }^{1}$ Percent change equals non-retired expenditures for 60-64 year olds minus the retired 65-69 year olds of the same cohort divided by the non-retired 60-64 expenditures.

Notes: All data are in real \$2003 using the CPI-U-RS item indexes. We calculate median equivalent expenditures using the square root of family size as the equivalence scale. We weight all data to be representative of the U.S. elderly population. Our unit of observation is the individual. 


\section{TABLE 4}

\section{HOUSING AS A PERCENTAGE OF CONSUMPTION EXPENDITURES AND CONSUMPTION FLOWS}

\section{COHORT 1}

Housing outlays as $\%$ of expenditures

Housing flow as \% of consumption flows

\section{COHORT 2}

Housing outlays as $\%$ of expenditures

Housing flow as $\%$ of consumption flows

\section{COHORT 3}

Housing outlays as \% of expenditures

Housing flow as \% of consumption flows

\section{COHORT 4}

Housing outlays as \% of expenditures

Housing flow as $\%$ of consumption flows

\begin{tabular}{|c|c|c|c|c|c|c|}
\hline $50-54$ & $55-59$ & $60-64$ & $65-69$ & $70-74$ & 75-79 & 80 plus \\
\hline 1984 & 1988 & 1993 & 1998 & 2003 & & \\
\hline 27.2 & 28.9 & 27.0 & 31.8 & 28.6 & & \\
\hline \multirow[t]{10}{*}{38.9} & 40.2 & 37.7 & 43.1 & 45.5 & & \\
\hline & 1984 & 1988 & 1993 & 1998 & 2003 & \\
\hline & 28.4 & 27.5 & 27.1 & 31.6 & 27.4 & \\
\hline & 38.5 & 38.8 & 41.2 & 44.1 & 47.0 & \\
\hline & & 1984 & 1988 & 1993 & 1998 & 2003 \\
\hline & & 31.2 & 29.1 & 29.7 & 29.5 & 31.7 \\
\hline & & 43.6 & 41.5 & 42.6 & 50.0 & 52.0 \\
\hline & & & 1984 & 1988 & 1993 & 1998 \\
\hline & & & 29.1 & 27.1 & 30.0 & 34.7 \\
\hline & & & 41.6 & 44.5 & 42.1 & 52.3 \\
\hline
\end{tabular}

Source: Consumer Expenditure Survey (CEX): 1984-2003.

Notes: To calculate the shares, we find the individuals in the 45th to 55th percentiles of consumption-expenditures distribution for each cohort-year pair. Then we find the mean housing outlay for this part of the distribution and divide it by the mean consumption expenditures for this part of the distribution. We weight all data to be representative of the U.S. elderly population. Our unit of observation is the individual. 


\section{TABLE 5}

MEDIAN EQUIVALENT CONSUMPTION-FLOWS BY COHORT AND AGE

\section{COHORT 1}

All

Not retired

Retired

$\%$ change $^{1}$

\section{COHORT 2}

All

Not retired

Retired

$\%$ change $^{1}$

\section{COHORT 3}

All

Not retired

Retired

$\%$ change $^{1}$

\section{COHORT 4}

All

Not retired

Retired

$\%$ change $^{1}$

\begin{tabular}{|c|c|c|c|c|c|}
\hline $50-54$ & 55-59 & $60-64$ & 65-69 & $70-74$ & $75-79$ \\
\hline 1984 & 1988 & 1993 & 1998 & 2003 & \\
\hline 20,831 & 21,430 & 19,583 & 22,969 & 21,738 & \\
\hline 20,530 & 21,470 & 19,272 & 23,360 & 23,908 & \\
\hline 25,327 & 19,858 & 20,866 & 22,374 & 21,356 & \\
\hline & & & $16.1 \%$ & & \\
\hline
\end{tabular}

\begin{tabular}{|r|r|r|rr}
1984 & 1988 & 1993 & 1998 & 2003 \\
20,410 & 20,252 & 20,830 & 21,238 & 21,976 \\
20,342 & $\mathbf{2 0 , 7 4 6}$ & 22,171 & 24,442 & 22,218 \\
22,462 & 19,404 & $\mathbf{1 9 , 8 4 3}$ & 20,503 & 21,889 \\
& & $\mathbf{- 4 . 3 \%}$ & & \\
\hline
\end{tabular}

\begin{tabular}{rr|rrr}
1984 & 1988 & 1993 & 1998 & 2003 \\
18,749 & 18,699 & 19,032 & 18,952 & 20,476 \\
$\mathbf{1 8 , 6 9 2}$ & 19,643 & 19,989 & 18,952 & 18,307 \\
19,213 & $\mathbf{1 8 , 4 6 2}$ & 18,614 & 18,967 & 20,622 \\
& $\mathbf{- 1 . 2 \%}$ & & & \\
& & & & \\
& 1984 & 1988 & 1993 & 1998 \\
& 19,592 & 19,469 & 17,696 & 18,685 \\
& 20,401 & 19,399 & 14,636 & 18,153 \\
& 19,452 & 19,614 & 18,483 & 18,730
\end{tabular}

Source: Consumer Expenditure Survey (CEX): 1984-2003.

${ }^{1}$ Percent change equals non-retired expenditures for 60-64 year olds minus the retired 65-69 year olds of the same cohort divided by the non-retired 60-64 expenditures.

Notes: All data are in real \$2003 using the CPI-U-RS item indexes. We calculate median equivalent expenditures using the square root of family size as the equivalence scale. We weight all data to be representative of the U.S. elderly population. Our unit of observation is the individual. 


\section{TABLE 6}

\section{RETIREMENT CONSUMPTION PUZZLE ESTIMATES BY CONSUMPTION MEASURE}

\author{
Percent change \\ at retirement ${ }^{1}$
}

$-5.7$

$-2.5$

2.6

\author{
95\% confidence \\ interval $^{2}$ \\ [-11.4 to -0.7$]$ \\ [-3.1 to 10.6$]$
}

Source: Consumer Expenditure Survey (CEX): 1984-2003.

1 For this table, we combine cohorts to arrive at one estimate of the consumption puzzle per measure of consumption. Because the sample sizes differ for each cohort and because we use the sample weights, the numbers presented in this table are not simple averages of their equivalent values in the respective tables.

2 We bootstrapped the standard errors using 10,000 replications.

Notes: All data are in real $\$ 2003$ using the CPI-U-RS item indexes. We calculate median equivalent expenditures using the square root of family size as the equivalence scale. We weight all data to be representative of the U.S. elderly population. Our unit of observation is the individual. 


\section{TABLE A1}

\section{SAMPLE SIZE AND PERCENT RETIRED BY COHORT AND AGE}

\begin{tabular}{lrrrrrrr}
\multicolumn{1}{c}{ AGE } & $50-54$ & $55-59$ & $60-64$ & $65-69$ & $70-74$ & $75-79$ & 80 plus \\
COHORT 1 & $\mathbf{1 9 8 4}$ & $\mathbf{1 9 8 8}$ & $\mathbf{1 9 9 3}$ & $\mathbf{1 9 9 8}$ & $\mathbf{2 0 0 3}$ & & \\
Observations & 650 & 632 & 577 & 536 & 707 & & \\
Percent retired & 2.6 & 4.5 & 21.1 & 58.4 & 75.1 & & \\
& & & & & & & \\
COHORT 2 & & $\mathbf{1 9 8 4}$ & $\mathbf{1 9 8 8}$ & $\mathbf{1 9 9 3}$ & $\mathbf{1 9 9 8}$ & $\mathbf{2 0 0 3}$ & \\
Observations & & 712 & 687 & 569 & 498 & 626 & \\
Percent retired & & 5.7 & 22.8 & 53.5 & 76.3 & 79.5 & \\
& & & & & & & \\
COHORT 3 & & & $\mathbf{1 9 8 4}$ & $\mathbf{1 9 8 8}$ & $\mathbf{1 9 9 3}$ & $\mathbf{1 9 9 8}$ & $\mathbf{2 0 0 3}$ \\
Observations & & & 630 & 605 & 546 & 384 & 730 \\
Percent retired & & & 20.7 & 55.4 & 67.6 & 84.6 & 86.4 \\
& & & & & & & \\
COHORT 4 & & & & $\mathbf{1 9 8 4}$ & $\mathbf{1 9 8 8}$ & $\mathbf{1 9 9 3}$ & $\mathbf{1 9 9 8}$ \\
Observations & & & & 596 & 461 & 379 & 419 \\
Percent retired & & & & 55.5 & 66.7 & 74.5 & 84.5
\end{tabular}

Source: Consumer Expenditure Survey (CEX): 1984-2003.

Notes: An individual is retired if he/she reports not working in the past year and states that the reason for not working is that he/she is retired. We weight all data to be representative of the U.S. elderly population. Our unit of observation is the individual. 


\section{TABLE A2}

COMPARISON OF EXPENDITURE SHARES TO BUTRICA ET AL (2005)

Butrica, Goldwyn, and Johnson (2005)

using the Health and Retirement Survey*

$\begin{array}{lrrr}\text { Ages } & \mathbf{5 3 - 6 4} & \mathbf{6 5 - 7 4} & \mathbf{7 5} \text { plus } \\ \text { Housing } & 0.36 & 0.32 & 0.32 \\ \text { Health care } & 0.12 & 0.16 & 0.20 \\ \text { Food } & 0.11 & 0.14 & 0.13 \\ \text { Clothing } & 0.05 & 0.03 & 0.02 \\ \text { Transportation } & 0.14 & 0.12 & 0.12 \\ \text { Entertainment } & 0.11 & 0.13 & 0.08 \\ \text { Gifts } & 0.07 & 0.06 & 0.09 \\ \text { Other durables } & 0.05 & 0.04 & 0.05\end{array}$

Consumer Expenditure Survey (2000-2001)**

$\begin{array}{lrrr}\text { Ages } & \mathbf{5 3 - 6 4} & \mathbf{6 5 - 7 4} & \mathbf{7 5} \text { plus } \\ \text { Housing } & 0.33 & 0.30 & 0.34 \\ \text { Health care } & 0.09 & 0.15 & 0.21 \\ \text { Food } & 0.14 & 0.17 & 0.18 \\ \text { Clothing } & 0.04 & 0.04 & 0.03 \\ \text { Transportation } & 0.12 & 0.11 & 0.09 \\ \text { Entertainment } & 0.12 & 0.12 & 0.08 \\ \text { Gifts } & 0.06 & 0.07 & 0.05 \\ \text { Other durables } & 0.08 & 0.05 & 0.02\end{array}$

* The shares from Butrica, Goldwyn, and Johnson (2005) come from Table 1 of their paper. We use the columns for "All" households.

** The CE data comes from the 2000-2001 survey years to match the years in the HRS. The shares represent the mean share for the households in the $45^{\text {th }}$ to $55^{\text {th }}$ percentiles of the distribution 


\section{RECENT WORKING PAPERS FROM THE \\ CENTER FOR RETIREMENT ReSEARCH AT Boston COLLEGE}

Life is Cheap: Using Mortality Bonds to Hedge Aggregate Mortality Risk

Leora Friedberg and Anthony Webb, October 2005

How Much Is the Working -Age Population Saving?

Alicia H. Munnell, Francesca Golub-Sass, and Andrew Varani, October 2005

Top Ten Myths of Social Security Reform

Jeffrey R. Brown, Kevin Hassett, and Kent Smetters, October 2005

What Replacement Rates Do Households Actually Experience in Retirement? Alicia H. Munnell and Mauricio Soto, August 2005

Bequests, Inheritances and Family Traditions

Donald Cox and Oded Stark, August 2005

Local Labor Market Conditions and Retirement Behavior

Dan A. Black and Xiaoli Liang, May 2005

Design and Implementation Issues in Swedish Individual Pension Accounts

R. Kent Weaver, March 2005

Lashed to the Mast?: The Politics of Notional Defined Contribution Pension Reforms

Sarah M. Brooks and R. Kent Weaver, January 2005

Understanding Expenditure Patterns in Retirement

Barbara A. Butrica, Joshua H. Goldwyn, and Richard W. Johnson, January 2005

Changes in the Distribution of Long-Run Earnings and Retirement Incomes-Have Recent Cohorts Fallen Behind?

Peter Gottschalk and Minh Huynh, January 2005

The Age Profile of Income and the Burden of Unfunded Transfers in Four Countries: Evidence from the Luxembourg Income Study

Gary Burtless, December 2004

All working papers are available on the Center for Retirement Research website

(http://www.bc.edu/crr) and can be requested by e-mail (crr@bc.edu) or phone (617-552-1762). 